\title{
Local Wisdom of The Lomban Tradition (Sedekah Laut) As An Effort Sustainable Development of Environmental Stability For Coast Community
}

\author{
Naila Rahmaniyatul Wulida ${ }^{1}$, Gaby Lasmaria Rajagukguk ${ }^{2}$, Akbar Kurniawan ${ }^{3}$, Thriwaty \\ $\mathrm{Arsal}^{4}$ \\ \{nenaila240@gmail.com¹, gabylasmaria12@gmail.com², akbarkurniawan21@ gmail.com², \\ thriwaty_arsal@mail.unnes.ac.id $\left.{ }^{4}\right\}$ \\ 1,2,3,4 Universitas Negeri Semarang, Indonesia
}

\begin{abstract}
The city of Jepara as a port city with the existence of its marine wealth has a tradition every Shawwal month which is often referred to as Lomban. This tradition does not only contain the religious, socio-cultural, and economic values of the community but also contains the value of local wisdom in preserving the environment. Lomban is a form of tradition offerings to the sea. Especially in Jepara, the buffalo head is usually used as the main material to be offered. This tradition contains local wisdom that supports sustainable development efforts for Indonesia. This study aims to find out how the offerings procession in Lomban's tradition and the values of local wisdom as sustainable development that affects their awareness in efforts to stability the environment. This study uses a qualitative descriptive approach to give a careful description of certain condition or symptoms in the object of study. Techniques for collecting data through Participatory Observation, In-depth Interviews, and literature studies. The result show that Lomban's tradition in Jepara is often done a week after Eid al-Fitr with several processions that color before and after the offerings. This tradition as a representation of expressions of gratitude, asking for safety and blessing to the God. In addition, the values of local wisdom in the tradition cover all aspects of human life. The natural materials used in the offerings indirectly give them awareness in an effort to stability the environment as sustainable development.
\end{abstract}

Keywords: Local Wisdom, Lomban, Sustainable Development, Environmental Stability

\section{Introduction}

The environment becomes one of the tools that affects human life. Humans and the environment are interconnected and have a unity of cause and effect. Therefore, the environment needs to be protected and protected from damage. The use of the environment needs to be well optimized to become a friend of mankind in fulfilling their daily needs. As for what is meant by the environment as stated in the Environmental Management Law No. $23 / 1997$ is as follows.

The unity of space with all objects, power, circumstances, and living things, including human beings and their behavior that affects the survival and welfare of humans and other living beings.

The environment includes all natural resources such as land, water, solar energy, minerals, flora and fauna that grow on land (land) and in the oceans [1]. 
The sea is an important element for human activity. Human life and activities in it that rely more on the sea are coastal communities or fishermen. The sea is at the heart of their economy which can help them fulfill their needs. Fish, sea plants, shellfish, etc. are wealth in the sea that are often used by coastal communities and other communities. In addition to the sea, the sea has natural beauty outside such as beaches, sand and trees. This becomes a potential for the sea area. This potential can be optimally useful if the surrounding community maintains this potential well.

Coastal communities as people who are more dependent on the natural sea, they try to use the resources in it well. If they damage it, it will affect for themselves. However, if they are good at keeping it, they will get the benefits it. Referring to the norms or customs of coastal communities in keeping the sea, they have a tradition that is often referred to as Lomban in an effort to respect the sea and as an expression of their gratitude to God. This tradition is one of their ways maintain the values of local wisdom to preserve the environment.

Local wisdom is a way of thinking and acting in accordance with ancestral cultural values. The view of life and the noble values that live in traditional societies in Indonesia, are increasingly recognized to have high wisdom in their interactions with nature [2].

Many other people outside of them consider this tradition to violate the actual rules or norms. They are considered to damage the sea by carrying out Lomban's tradition. This tradition uses the head of a buffalo to be dissolved into the sea. Lomban raised some thoughts between the pros and cons among the people. Even though, coastal communities that carry out these traditions feel confident about religious values and environmental conservation. This tradition carried out by coastal communities in Jepara Central Java can indirectly help efforts for sustainable development for underwater life, the natural environment and its surroundings.

The goal of sustainable development or in English is called the Sustainable Development Goals is a global agenda from the United Nations issued in September 2015 as an effort to continue the previous global agenda of MDGs (Millennium Development Goals) that have given better achievements in changing the face of the world. Kumar, S., Kumar, N., \& Vivekadhish, S. (2016) [3] say "SDGs include a vibrant vision of building and systematic partnerships with private sectors to achieve sustainable development. It builds on the UN Compact which was launched in 2000 and IMPACT 2030 ". SDGs include the vision of building partnerships and or dynamic and systematic cooperation with the private sector to achieve sustainable development.

Sustainable development is defined as development that is endless and continues. Sustainable development is intended to provide a better level of life for future generations. Environmental sustainability is needed for economic, social and cultural growth. There needs to be a balance in carrying out development efforts and environmental preservation to ensure sustainable development.

\section{Research Method}

This study uses a descriptive method with a qualitative approach, which is done to find, develop, and prove certain knowledge so that it can be used to understand, solve, and anticipate problems [4]. In addition, the selection of this approach is expected to provide a careful description of certain conditions or symptoms in the object of study.

The researchers conducted in-depth interviews with the navy military police who live on the beach, religious leader who lead the Lomban's tradition, and some of the surrounding community consist of the people who live there and the sellers on the beach. 
The focus of the research is to understand the form of Lomban's local wisdom in Jepara coastal communities and how this tradition is one of the efforts to preserve the environment in sustainable development. Research location is in the city of Jepara, Central Java. Techniques for collecting data through direct observation, in-depth interviews, and literature studies in the form of photos, archives, news, and so on.

\section{Result and Discussion}

\subsection{Jepara City is An Port City}

The name of Jepara comes from the word ujung and para. The word Para is short for Pepara which means "bebakulan mrana-mrana", which is trading here and there. Meanwhile Lekkerkerker called Jepara with haventjes der klein handelaars, it means the port of small traders. Jepara is located in the north of the island of Java. The city of Jepara is known not only as a carving city with the beauty of its carvings, but also is known as the port city. The city of Jepara as a port city has the existence of the wealth of the earth, with its many seas.

\subsection{Procession of Lomban's Traditions}

Lomban is a tradition of dissolving offerings made intentionally by the people into the middle of the sea as a symbol of their gratitude to God who has given him sustenance from these marine resources. Lomban's tradition is carried out by fishing communities living in the coastal areas in Jepara. In addition over the times, this tradition not only attended by fishing community but also visitors and communities outside the area. This tradition is also carried out in several fishing communities in other areas, but in each region it has distinctive characteristics, traditions and processions of traditions. Lomban in the city of Jepara has a distinctive use of buffalo heads as the main offerings which will be dissolved into the sea.

The lomban tradition is held every seventh day after Eid al-Fitr for Muslims. Lomban's ritual starts at 6 am until it's finished. The sacredness of the lomban tradition is in the morning ritual section. The venue was started from Ujung Batu village in TPI (Fish Disposal Site) and ended in the middle of the sea in Kartini Beach.

Following is the procession of the lomban tradition in the city of Jepara (Kartini Beach):

1. Begin by making miniature medium-sized vessels to place offerings that will be dissolved. Ship made of bamboo.

2. Slaughtering buffalo. At first, their only bought buffalo heads when carrying out the tradition. Other members of the body were not bought. Along with the development of the times, they slaughtered one-tailed buffalo, their heads were used offerings in offered, other limbs were cooked to be eaten together with Javanese Ketupat.

3. Prayer together. This shows that the lomban tradition is not a shirk ritual. The prayer was led by the community's religious leaders.

4. Delivery of buffalo head offerings and other complementary offerings to the middle of the sea. In this procession the arranged offerings in a miniature ship are placed on a large ship belonging to one of the fishermen. The large ship was followed by other small ship owned by fishermen.

5. Offered in the middle of the sea. When a miniature ship containing a buffalo head was offering into the middle of the sea, the ships that followed it scrambled towards 
the offer. They washed their ships with water around the ship containing the buffalo head.

There are various perspectives about implementation of the lomban tradition. People value this tradition from several points of view. Most still believe in the existence of magical power in the tradition. They think that this tradition respects the guardians of the sea and avoids danger. But there are also those who think this tradition as a form of gratitude to God Almighty. The lomban tradition is a tradition to preserve ancestral culture, maintain local traditions and local wisdom.

\subsection{Local Wisdom Value of Lomban's Tradition}

According to Siombo (2019) [2] local wisdom criteria that related to environmental management and maintenance consist of :

1. Noble values that apply in the system life of the community

2. Protect and manage the environment in a sustainable way.

Lomban's tradition has local wisdom values that indirectly can help efforts to preserve the environment. The values of local wisdom include in 3 fields, namely religious, social-cultural, and economic [5].

\section{Religious}

The lomban tradition is a relationship of friendship and is not shirky at all from the tradition of offering with buffalo head. It is only symbolic. The blessings that the people want come from God Almighty not from the head of the buffalo.

\section{Socio-Cultural}

In society, this traditional can raise awareness of a sense of oneness in society. In culture, this tradition creates awareness of preserving local culture that cares about the sea.

\section{Economy}

The Lomban tradition can provide opportunities for the people there to become entrepreneurs by trading so as to increase their income.

Local wisdom values of Lomban's tradition in Jepara's community that related to the environment is a typical idea and has been applied for generations. This becomes self defense or a fortress in protecting and keeping sustainability of natural resources from exploitation and human's greed.

\subsection{Lomban As an effort for SDG's Environment}

The Lomban's tradition can inderectly help efforts to preserve the environment including the sea. A series of events ranging from pre-progam to post-progam can continue to become SDG's on the environment. In pre-progam, the Lomban's tradition is accompanied by activities to clean the marine in mutual cooperation. Effort to clean the sea from garbage can make the sea fresh again.In addition, the Lomban's tradition which is decorated with buffalo head and other offerings can continue to turn into a food chain process.

The lomban tradition has a main offering in the form of a buffalo head, accompanied by supporting offerings such as rice, chicken opor, and the like that come from nature. Referring to the ingredients of the offerings used, they all come from nature and will return to nature. The offerings will be eaten by fish in the sea. Then, the fish will be lured by the fishing community. The fishing community that holds the lomban tradition as gratitude and thanks for the abundant marine wealth. Thus, the community indirectly makes SDG's efforts to the environment through the Lomban tradition which is conducted once a year. 
The following is Lomban's description of SDG's Environmental efforts.

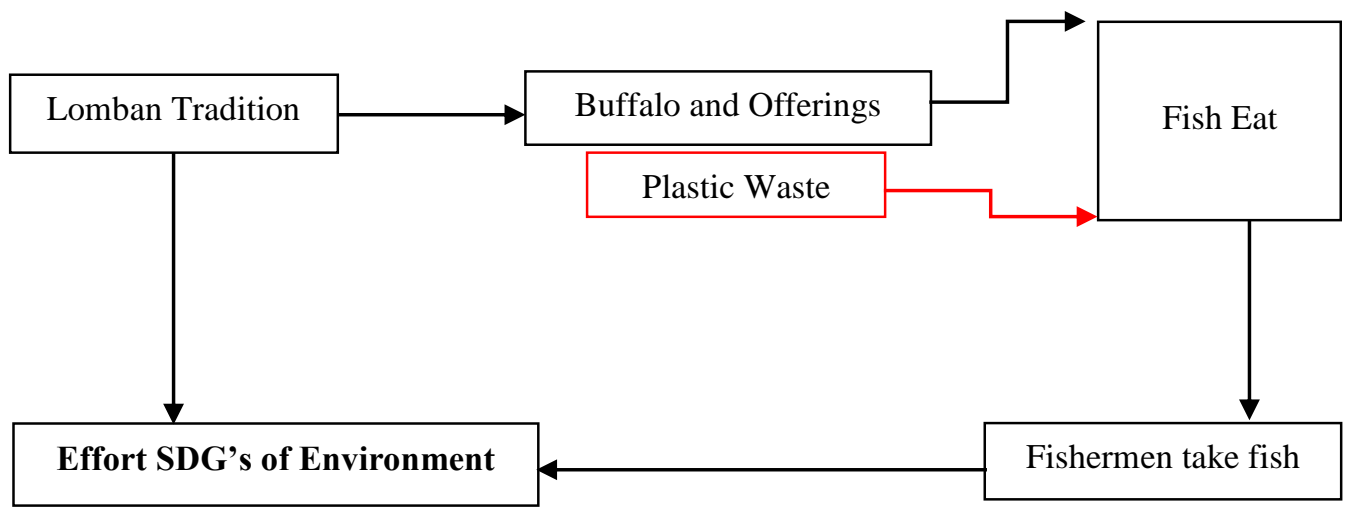

\section{Information:}

Red: Fish doesn't eat rubbish

Referring to the research of an Anthropologist Prof. Dr. Judith Schlehe and Visia Ita Yulianto (2018) [6] entitled "Waste, worldviews and morality at the South Coast of Java: an anthropological approach" states that most of the fish in the sea have eaten scattered rubbish into the ocean;

"Maritime debris experts point out that Indonesia is the world's second-biggest marine pollutant, tossing approximately 1.3 million tons of waste annually into waters.

Nowadays, 5, 25 trillion pieces plastic are swirling around in the world ocean. This is nearly equivalent to the entire land mass of Indonesia."

Based on the statement above, the relation to the lomban tradition carried out by fishing communities is it can indirectly reduce littering behavior on the sea. Instead of rubbish which is food for fish, it is better to offer offerings from the lomban tradition which become food. Therefore, for the Jepara fishing community, it is better to do the buffalo head and other offerings that are of natural origin rather than to dissolve rubbish. Garbage can clearly pollute the environment because it is difficult to decompose.

\section{Conclusion}

The sea is an important element for human activity. Human life and activities in it that rely more on the sea are coastal communities or fishermen. They have traditions that they believe can help protect their environment. One of the fishing communities in the city of Jepara does the Lomban tradition every year. Tradition is a symbolic sense of gratitude for the Almighty God.

Lomban in the city of Jepara has a distinctive use of buffalo heads as the main offerings which will be dissolved into the sea. This tradition contains local wisdom values covering the fields of religion, socio-culture, and economy. Lomban's tradition can indirectly reduce 
littering on the sea. This shows that Lomban's tradition is one of the efforts of the Sustainable Development Goals of Environment, especially in the marine environment.

\section{Suggestion}

As an environmentally conscious society, we must maintain and preserve cultural values that can protect nature indirectly. Humans and nature need each other in life. Nature needs to be protected especially the sea that has a lot of wealth in it.

\section{References}

[1] M. Suparmoko, "Ekonomi Sumber daya Alam dan lingkungan," 2014.

[2] M. R. Siombo and M. SH, Dasar-Dasar Hukum Lingkungan dan Kearifan Lokal Masyarakat. Penerbit Atma Jaya, 2019.

[3] S. Kumar, N. Kumar, and S. Vivekadhish, "Millennium development goals (MDGS) to sustainable development goals (SDGS): Addressing unfinished agenda and strengthening sustainable development and partnership," Indian J. community Med. Off. Publ. Indian Assoc. Prev. Soc. Med., vol. 41, no. 1, p. 1, 2016.

[4] Sugiyono, Metode Penelitian Pendidikan Pendekatan Kuantitatif, Kualitatif, dan R \& D. Bandung: Alfabeta, 2009.

[5] D. P. Ningsih, "The Value of Local Wisdom In Jepara's Lomban Tradition," J. Ilm. Mandala Educ., vol. 3, no. 2, pp. 173-180, 2017.

[6] J. Schlehe and V. I. Yulianto, "Waste, worldviews and morality at the South Coast of Java: an anthropological approach," Occas. Pap., no. 41, 2018. 